\title{
The identification and examination of
}

\section{the elements that caused a schism in}

the Johannine community at the end of

the first century CE

\author{
Dirk van der Merwe \\ Department of New Testament \\ University of South Africa
}

\begin{abstract}
A group of people within the Johannine community (2:18) contributed towards destroying the koเvwvia (fellowship) of this community. Because 1 and 2 John do not provide direct evidence of the identities of the community's heretically inclined members, they are defined in different ways by different scholars. A search for socio-religious circumstances which contribute towards determining the opponents and adherents of the author which created the agenda for the reconstruction of the phenomena that caused this schism. The nature of the schism comprises "Pneumatological," "Christological" and "ethical" issues encoded in the polemical language of slogans, dialectic discourse, confessions and denials. The schism in 1 John proves to be a matter of different interpretations of a shared tradition.
\end{abstract}

\section{INTRODUCTION}

The first Christian century can be depicted as a period of relative peace and stability for the Roman Empire, a period which was known as the Pax Romana. ${ }^{1}$ For the new born Christian Church it was certainly not the case. A

\footnotetext{
${ }_{1}^{1}$ Pax Romana (27 BC-AD 180), Latin for "the Roman peace", is the long period of relative peace experienced by states within the Roman Empire. The term stems from the fact that Roman rule and its legal system pacified regions, sometimes forcefully, which had suffered from the quarrels between rival leaders (http://en.wikipedia.org/wiki/Pax_Romana; http://www.encyclopedia.com/doc/1B1-374732.html; http://history.enotes.com/history-factfinder/eras-their-highlights/what-was-pax-romana). Though the use of the word "Peace" may be a bit misleading, this period refers mainly to the great Romanization of the western world. The Roman legal system which forms the basis of many western court systems today brought law and order to the provinces. The Legions patrolled the borders with success, and though there were still many foreign wars, the internal empire was free from major invasion, piracy or social disorder on any grand scale (http://www.unrv.com/early-empire/pax-romana.php).
} 
number of the New Testament documents are concerned with controversy and hostility, or at least reflect indirectly the existence of it in some of the communities. The need to address this problem in the various Christian communities where it occurred, contributed positively to the formulation of the doctrine and ethics of the church. This was surely the case as far as the Johannine epistles are concerned. Hence, from the evidence of the New Testament it seems that the time in which the New Testament was written was marked by great confusion with conflicts outside and inside the Church between groups and individuals who claimed to speak the truth.

From 1 and 2 John, commonly accepted among scholars as originating from the same early Christian circles, it is clear that a serious internal crisis developed among these believers subsequent to the expulsion of Johannine Jewish Christians from the Jewish community. Throughout these epistles the situation is depicted as a schism that has already started to occur in the community. $^{2}$

This research deals with the identification and examination of the elements that caused the controversy and schism in the Johannine epistles, and focuses on only the first two epistles. ${ }^{3}$ In investigating this schism, the interest will naturally focus on 1 John, the longest of the three Epistles. As far as method is concerned, this research will be approached socio-rhetorically. First, the socio-religious situation in the Johannine community, with concentration on how the Elder depicted the opponents and his adherents, will be examined. Second, the features of the schism in this community will be identified and examined. ${ }^{4}$

\footnotetext{
${ }^{2}$ The exact social description or label of the Johannine community is still a matter of debate. Is it a community (Brown, R 1979), a sect (Meeks 1972:44-72; cf Bogart 1977:136-141; see Keener 2003:149 \& Fuglseth 2005 who argue against this community being a sect; also see on the definition of "sect", Rensberger 1988:136), a circle (Cullmann 1976; cf also Painter 2002:75-76), a "Konventikel" (Käsemann 1978), a school (Culpepper 1975 \& Strecker 1996:xxxv), a group (Van der Watt 2006:121), etc? Because of this uncertainty the reference "Johannine community" will be used for the group of Johannine Christians. Such an indication tends to be more neutral.

${ }^{3}$ The other Johannine epistle ( $3 \mathrm{Jn}$ ) does not offer evidence of this crisis and is not so concerned with Christological or pneamatological issues. Hospitality (an ethical issue) seems to be the issue there. It may be deducted that it may have been written in a different situation in the Johannine community. Therefore, it was not regarded as important and relevant to the discussion in this article. For more on the dispute between the Elder and Diotrephes, please consult the section "Hospitality and Inhospitality" (pp 92-112) in Malherbe A J (1983). Social aspects of early Christianity, 2nd edition. Philadelphia, PA: Fortress.

${ }^{4}$ The academic contribution of this research lies in the comprehensive socio-rhetorical investigation of this topic; which is also done from the perspective of the familia Dei and finally, which not only look at the conventional Christological and ethical aspects that caused the schism, but adds a third and neglected aspect, namely that of pneumatology.
} 
The socio-religious situation of the Johannine community will now be discussed.

\section{THE SOCIO-RELIGIOUS SITUATION IN THE JOHANNINE COMMUNITY}

\subsection{The depiction of the opponents of the Elder}

Numerous attempts have been made to identify the "opponents" of the Elder. ${ }^{5}$ They were depicted as charismatics, Jewish Christians, Cerinthians, Docetists, and Gnostics. ${ }^{6}$ While these opponents have some points (characteristics) in common with the proposed depictions, differences militate against a precise identification with any of these groups. ${ }^{7}$ It can be taken for granted that none of these identifications is absolutely convincing. Therefore, the identification of these opponents as such would not have been particularly enlightening; considering how little we know about these groups, it would be to explain ignotum per ignotius (to explain) something not understood by one still less understood; Brown 1982:69ff; cf also Schnackenburg 1992:17). This does not mean that "opponents" did not exist, but only that the precise historical situation is not known to us.

Within the framework of this investigation, these opponents can perhaps be best identified through a study of the three key passages: 1 John 2:18-27; 4:1-6 and 2 John 7-11. Here the Elder reinterpreted his opponents as

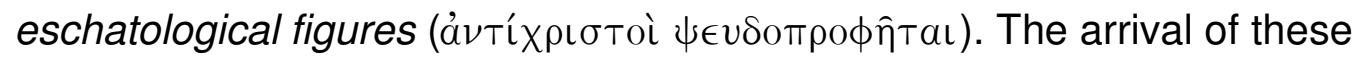
antichrists is referred to, twice by him, as "it is the last hour" (2:18bis, é $\sigma \chi a ́ T \eta$

\footnotetext{
${ }^{5}$ In this chapter it has been accepted, in agreement with the point of view of most scholars, that the three Johannine epistles were written by the same person, referred to in 2 John 1 and 3 John 1 as the $\pi \rho \epsilon \sigma \beta \dot{\tau} \epsilon \rho 0 S$ (Brown 1979:398; Culpepper 1998:251; Kenney 2000b:12; Painter 2002:18; Thomas 2004:4). Therefore, the author will be referred to as "the Elder".

${ }^{6}$ See Filson 1969:268ff; Brown 1982:55ff; Edwards 1996:57ff; Hurtado 2003:418 for a discussion on these depictions; also cf Culpepper 1998:51. Brown (1982:55) also added the Ebionites and libertines.

${ }^{7}$ Any attempt to discover the precise nature of the crisis within the Johannine community is made more difficult because of the fact that there is so much disagreement about the interpretation of 1 John. A glance at some commentaries and other publications on 1 John illustrate just how divergent this interpretation is. See Filson (1969:68f); Bultmann (1971:9; 1973:11); Perkins (1979:xviff); Brown (1982:47ff); Grayston (1984:12f); Smalley (1984:xxiii); Schnackenburg (1992:17); Neufeld (1994:7f); Edwards (1996:59ff); Culpepper (1998:51); Painter (2002:88ff); Duling (2003:439); Hurtado (2003:418ff). The most striking feature that emerges from this review of these publications is the great diversity in the interpretation of the various aspects concerning the opponents of the Elder in 1 and 2 John. Those who left the community were seen as either Gentile Christians or Jewish Christians or both. Their deception has been interpreted as either doctrinal, or ethical, or both. Grayston (1984:19f) goes further and interprets it as the "exaggeration of the role of the Spirit". Von Wahlde (1990:128 n 17) points out that there are various ways of approaching the statements regarding the opponents.
} 


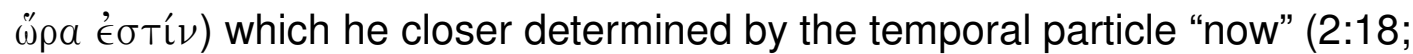
$4: 3, \nu \hat{\nu})$ as indicated below.

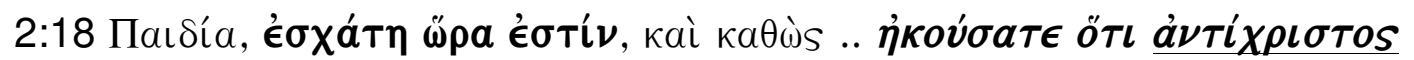

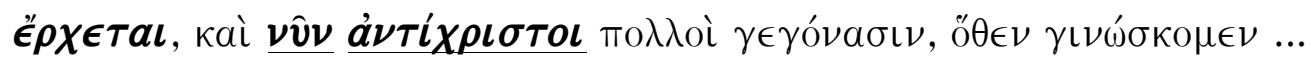

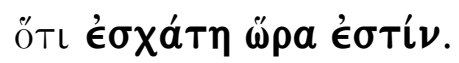

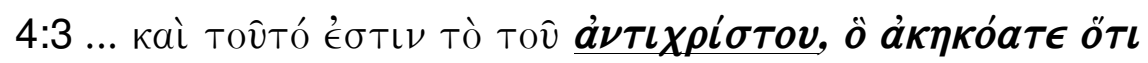

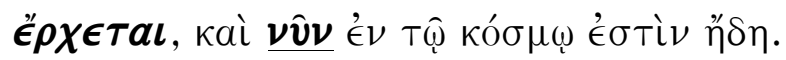

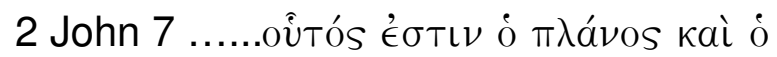

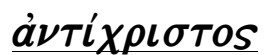

These phrases designates, according to the Elder, the final and decisive period in the history of mankind. ${ }^{8}$ The "last hour" is present, it is "now", because the antichrists are present in the world (1 Jn 2:18; 4:3; 2 Jn 7). The

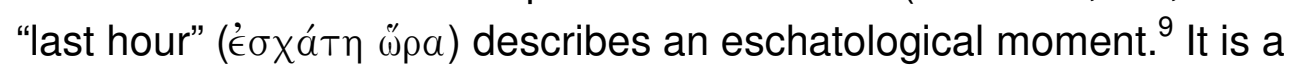
statement that it is the last hour in salvation history (Schnackenburg 1992:132; see Strecker 1996:62 for an opposite view) which has also to be understood in a future eschatological sense. Therefore, it is almost obvious that 2:18-27 ends with a reference to the future coming of Christ (2:28,

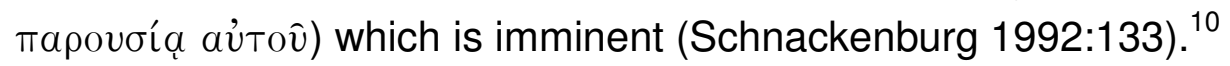

These passages delineate some aspects regarding the background of these opponents of the Elder:

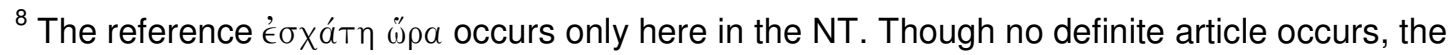
eschatological element is stressed by the reference to the coming of the Antichrist (Painter 2002:197; Haas, De Jonge \& Swellengrebel 1972:62). Comparable expressions are found in the Fourth Gospel: "the hour" (5:25, 28, also without the article), and "on the last day" (6:39f, 44,$54 ; 11: 24 ; 12: 48 ; 7: 37$ in not relevant). The definite article is always used, and the reference is always to the day of resurrection which clearly differs from the last "hour," which seems to refer to a period of time immediately leading up to the last day (Painter 2002:197).

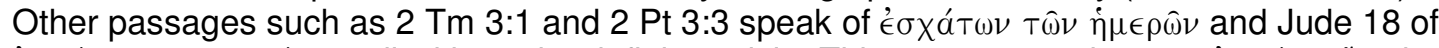

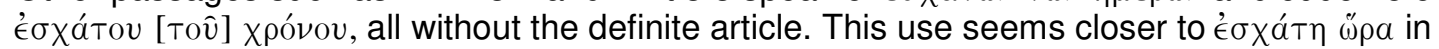
$1 \mathrm{Jn}$. In other passages (cf $3: 18 ; 4: 23 ; 5: 25$ ) the Fourth Gospel views the final decision as being a fact already.

${ }^{9}$ Danker (2000:1103) says the same when he defines $\ddot{p} p a$ in this context as "a point of time as an occasion for an event, time." Therefore, Schnackenburg, (1992:133) rightly states that the "last hour" does not mean the whole period since the coming of Christ or since his resurrection. Neither is it a phase or a particular period within time as it draws to its close. This reference also does not imply a precise chronological scheme for the Elder's eschatological understanding. With the warning about the "antichrists have come," the Elder only wants to say that his own time has an eschatological importance. See also Van der Merwe (2003:253ff) for the Fourth Evangelist's use of " $p a$ as a possible theological setting for the understanding Johannine eschatology.

${ }^{10}$ The imminence of the parousia by the Elder relates to the point of view by other Christian theologians: 1 Cor 7:29ff; 16:22; Rm 13:11; Phlp 4:5; 1 Th 5:1ff; 2 Th 2:2f; Heb 10:25, 37; Ja 5:8; 2 Pt 3:9; 1 Clem 23.2; Did 10.6; Barn 4.1ff; 21.3, 6; cf also Mk 13:6. Take note that in these texts no specific use of the noun "antichrist" occurs.
} 


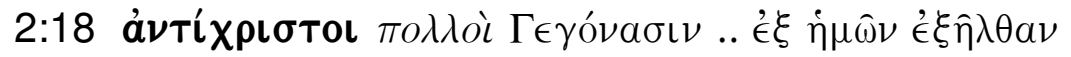
$4: 1$
$\pi о \lambda \lambda \circ \grave{~} \psi \in v \delta o \pi \rho \circ \phi \hat{\eta} т а \iota$.

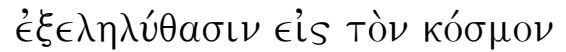
2 John 7
$\pi \circ \lambda \lambda \circ \grave{~ \Pi \lambda a ́ v o เ ~}$
$\dot{\epsilon} \xi \hat{\eta} \lambda \theta \mathrm{ov}$

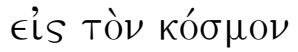

In these texts the Elder refers to the fact that in the schism apparently many ( be deduced that many people left the community. Since there is no inference that they left their environment, they could still have influenced the adherents of the Elder.

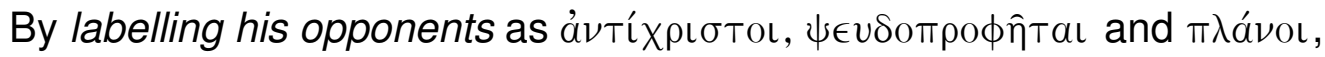
the Elder refers to unnamed people who had once been members of the Johannine group, but had subsequently abandoned their association with this group (2:19). Other references in this passage to "lies" (2:21), "liars" (2:22), and "those who would deceive you" ( $\tau \hat{\omega} \nu \pi \lambda \alpha \nu \omega \dot{\nu} \tau \omega \nu$ v $\mu \hat{\alpha} s, 2: 26$; cf. also 4:6) probably also refer to those who had left the Johannine community. They promoted a religious viewpoint that differed so much from "what they have heard from the beginning" (cf $1: 1 ; 2: 7,13,14,24$ ) that the Elder regarded it as an unacceptable innovation (Hurtado 2003:408f).

The term antichrist is used in the singular and the plural (2:18). Where the singular form is used, the reference may be to the principal leader of the opponents. It is almost unthinkable that the schism did not involve a leadership struggle. While no leader is named, the fluidity of the one Antichrist and the many antichrists suggests a leader and his schismatic followers. The names Deceiver, Liar and Antichrist seem to focus on the leader of the opponents. His followers are characterized in similar terms (Painter 2002:203). The reference in the plural form, made to the $\alpha \nu \tau i$ x $\rho\llcorner\sigma \tau o l ~(2: 18)$, $\psi \in$ of the impact of the schism and the activities of those who were, according to the Elder, false teachers, false prophets and deceivers.

That "they went out" ( $\left.{ }^{\epsilon} \xi \hat{\eta} \lambda \theta a \nu\right)$ implies that they were once part of the community and left of their own accord (Painter 2002:204). The phrase $\epsilon$ is Tò $\nu$ kó $\sigma$ o $\nu(4: 1 ; 2 \text { John } 7)^{12}$ is merely another way of stating emphatically that they have left the community and characterizes them as opposing those in the

\footnotetext{
${ }^{11}$ See Culpepper (1975), Johannine school; Cullmann (1976), Johannine circle and Brown (1979), Johannine community; cf. also Martyn (1979).

${ }^{12}$ Of the 23 occurrences of kó $\mu$ ov in 1 \& 2 John, only two $(4: 9,17)$ refer to locality. In 4:1-6 кó $\sigma \mu \mathrm{\nu}$ occurs six times. In all these cases it is used antithetically to God. The phrase "they have gone out into the world" (also $2 \mathrm{Jn} 7$ ) alludes to 2:19, where it is stated: "They went out from us", which infers that they were formerly part of the community but had severed all ties. See Schnakenburg (1992:199) for a different interpretation. "They went out from us ..." characterises their appearance in public all over the world. The adherents of the Elder may come upon them anywhere.
} 
community. They are of the world, while those in the community are of God (see 4:1-6).

Throughout 1 John the opponents are vehemently depicted and treated as existing outside the Johannine community ${ }^{13}$ and are (1) labelled according to the deeds they committed at the ethical level, on account of which they are

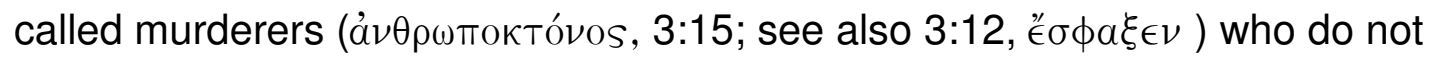
love a brother (4:20; also cf $2: 11 ; 3: 15)$, and at the doctrinal level, on account of which they are depicted as deceivers (2 Jn 7; also $1 \mathrm{Jn} 2: 26 ; 3: 7$ ), antichrists $(2: 18,22 ; 4: 3 ; 2$ Jn 8$)$, liars (2:22) and false prophets (4:1). (2) These deceivers are also described within specific relationships: concerning the devil they are seen "as children of the devil" $(3: 8,10)$; in relation to God they are depicted "as not from God" (3:10; 4:3, 6), "do not know Him" (God) (3:1), and "do (not) have fellowship with Him" (1:6); and finally they are seen as "to be in the world" (4:5). (3) Metaphorically speaking, in a reciprocal sense, it is said that they walk in the darkness and do not know the way to go, because the darkness has brought on blindness (2:11). (4) In probably the harshest description it is said that they "do not have life" (5:12; also 3:15) and "abide in death" (3:14). In most of these references the harsh depiction of these opponents is contrasted with the characteristics of the adherents of the Elder (Van der Merwe 2005:550).

\subsection{The depiction of the adherents of the Elder}

Contrary to his opponents the Elder depicted his adherents in the Johannine community, metaphorically as the family of God (familia Dei). The fellowship that existed in this family was torn apart by the deception of some of its members. In order to grasp these circumstances and consequences it is necessary to understand what the Elder meant when he depicted the community as the familia Dei, and what he understood under "fellowship in the family."

\footnotetext{
${ }^{13}$ Scholars refer to them differently. Painter (2002:84) refers to them as "opponents". According to him, they could also be called "schismatics" or "heretics" (2002:84). An

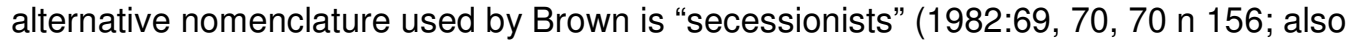
Hurtado 2003:409ff); he also refers to "adversaries" (1982:415, 574, 618), "opponents" and "deceivers" (1982:358f), and "propagandists" (1982:429). Schnackenburg (1992:18) calls them "heretical teachers". Each of these terms can be justified as representative of the Elder's point of view. See Hurtado (2003:418) for a brief discussion of why references to these secessionists as "docetists" or "Gnostics" are unacceptable.
} 


\section{- The Johannine community as the familia Dei}

In the ancient Mediterranean world, being part of a group was important and a matter of convention. ${ }^{14}$ The in-group of the Johannine community, and how the common life is lived within this group, were what mattered to the Elder, and this was the focus of his doctrine and ethics (cf Botha 2005:395-6). By reminding his adherents of their fictive

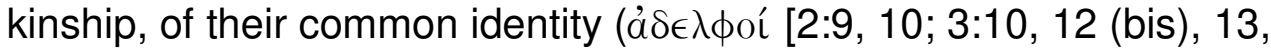

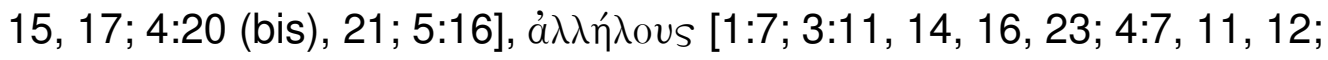
2 John 5]) and the values, conduct and doctrine that set them apart from other groups (e g their opponents) in their society, the Elder entrenched their identity as a group, and served to continue to regulate social behaviour in this group.

To this end, the Elder uses the most intimate social phenomenon in the ancient world, namely "the family"15 (Van der Watt 1999:494), to describe the existential reality of being and living as Christians in such a group. In doing so, he uses a coherent network of metaphors, related to the social reality of first-century family life (Van der Watt 1999:491; also Lassen 1997:103), to provide an understanding of fundamental Christian concepts. He applies widely accepted conventions from everyday life to what happens in the community, and uses generally accepted ideas about family life to explain what Christian life in the community comprises.$^{16}$ Therefore, the relevant social and family conventions of that time have to be considered for better understanding. In using these complex metaphors, developed in the text itself (cf Van der Watt 1999:493), the Elder focuses only on specific central and widely accepted and relevant aspects (Van der Watt 1992:272-9) that serve his purpose. In this way he tries to activate the social dynamic of the interrelatedness between a father and his child

\footnotetext{
${ }^{14}$ Malina (1982, 1986, 1993; 1996:64; Robbins 1996:101) points out how important group identity, real kinship and fictive kinship relations were in the first-century Mediterranean world - it fully determined the identities of individuals. Since they were group oriented, they were socially minded, attuned to the values, attitudes and beliefs of their in-groups. Because these people were strongly embedded in a group, their behaviour was controlled by strong social inhibitions along with a general lack of personal inhibition.

${ }^{15}$ In the New Testament, Jesus groups are described from a strongly "group-embedded, collectivistic perspective," perceiving themselves as forming "the household of God" (familia Dei). Sandnes (1997:156) points out "that in the family terms of the New Testament, old and new structures come together. There is a convergence of household and brotherhood structures. The New Testament bears evidence of the process by which new structures emerged from within the household structures."
}

\footnotetext{
${ }^{16}$ Achtemeier, et al (2001:547) assert that the family imagery may provide useful evidence regarding the internal structure and organisation of the Johannine community.
} 
and between children mutually in the minds of his adherents. Through all this he tries to redefine their position and relationship to one another. They constitute the family of God (familia Del). This familia Dei is the sphere where Christian fellowship is constituted and experienced.

Contrary to his opponents, who claimed fellowship with God, the Elder wants his adherents to be assured of the indwelling God through their abiding relationship with $\mathrm{Him}(2: 28 ; 5: 13)$ and with one another. The attitude, teaching and conduct of the opponents of the Elder annihilated this fellowship in the community. The Elder therefore wrote this epistle to encourage this kind of fellowship in the familia Dei and to promote the role and function of Jesus Christ in the constitution and realization of this fellowship in the community that had been abandoned by these opponents.

\subsection{Conclusion}

From the content of 1 and 2 John it is difficult to label the Elders' opponents with a specific epithet. ${ }^{17}$ The above analysis verified the fact that these opponents of the Elder were once part of the Johannine community and that they had shared the same tradition. Differences in the interpretation of this tradition caused the schism. Many members of the community, and this is a relative indication, went astray but remained in the vicinity region. They were probably influenced by an influential leader, referred to as the Antichrist. This is due to his contradictory confession regarding Jesus' identity. This historical event and the circumstances were reinterpreted by the Elder as an

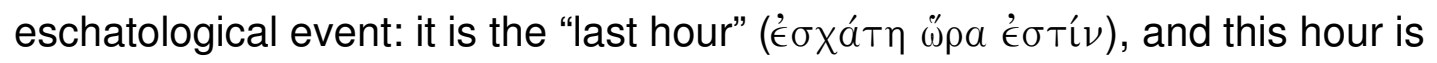
the hour of the coming of the Antichrist(s).

In 1:3 the Elder enunciates this objective. He desires his adherents to have fellowship with him and with his associates by sharing their experience of the manifested life $(1: 1,2)$; but fellowship with them meant simultaneous fellowship with the Father and his Son. ${ }^{18}$ This fellowship was broken because of the opponents' attitude of claiming true and vital knowledge through the Spirit for themselves, which led to their deviating Christology and conduct in the community. These three claims will now be discussed in order to provide the reader with a better understanding of the nature of the hostility and how it hampered fellowship in the community.

\footnotetext{
${ }^{17}$ See footnotes 7 and 13. From these epistles they can only be described and characterized.

${ }^{18}$ The opponents claim fellowship with God without fellowship with the Son and one another.
} 


\section{THE CONSTRUCTION OF PHENOMENA THAT CAUSED THE SCHISM IN THE JOHANNINE COMMUNITY}

Even though references are scattered throughout the epistle, the Elder is quite thorough in his description of the claims of his opponents. ${ }^{19}$ By studying the Elder's references to the opponents it is possible to piece together their claims of true divine knowledge and the outlines of their doctrine and ethics.

\subsection{A pneumatological issue: The claim of true and vital divine knowledge through the Spirit}

Hurtado (2003:415) provides an apt summary of the situation in the Johannine community at the time 1 and 2 John was written. According to him, a group arose in this community which based their Christological assertions on professed revelatory experiences of the Spirit (cf also Grayston 1984:20). The opponents of the Elder claimed a special illumination by the Spirit $(2: 20,27)$ that imparted to them true knowledge of God. This caused them to regard themselves to be the children of God. They claimed that their Christological views and their own spiritual status were superior (Hurtado 2003:416). It seems as if they believed that they had been given new and superior insight. They also may have claimed that they possessed (or had been given) fellowship with God that was superior to that enjoyed by other Johannine Christians, and that their higher spiritual status justified the severing of ties. It seems as if they were so thoroughly persuaded of the superiority of their inspiration that they removed themselves from the circle of the Johannine community (Hurtado 2003:424). For them their revelations validly superseded all previous understanding of Jesus and his significance. They drew upon Johannine traditions and even considered themselves the valid interpreters of those traditions. Nevertheless, in the opinion of the Elder they not only abandoned the ties of fellowship with other Johannine believers, but also departed from traditional Christological convictions. Their apparently volitional secession suggests that they were convinced that they had gone far beyond the level of understanding of those they abandoned (Hurtado 2003:419; Kenney 2000b:101; also Brown 1982:52; Lieu 1986:207).

Their new insights regarding Christ amounted to a notably different stance from what the Elder continued to see as binding tradition. Therefore, the Elder contrasts the opponents' claim to knowledge with the knowledge that can come only from the Christian tradition (2:24; cf also Culpepper

\footnotetext{
${ }^{19}$ See Grayston (1984:16ff) for an indication of all the possible views of the opponents contested by the Elder.
} 
1998:49) ${ }^{20}$ and the Spirit of God (4:2; 5:6). The Christological convictions of the opponents will now be discussed.

\subsection{The Christological issues: The denial that Jesus is "the Christ that came in the flesh"}

In order to understand the basic Christological tenets of the opponents in 1 and 2 John, we need to look at the confessional formulas that are brought to bear against them ( $1 \mathrm{Jn} 2: 22 ; 4: 2,3,15 ; 5: 1,5,6,10,13 ; 2 \mathrm{Jn} 7) .{ }^{21}$ The Christological focus in 1 John is the historical intersection of the divine and the human in Jesus. This intersection is asserted in what the Elder urges his readers to believe and confess: (1) "Jesus is the Christ" $(2: 22 ; 5: 1)$, "Jesus is the Son of God" (4:15; 5:5), (2) "Jesus Christ has (is) come in the flesh" (4:1$3 ; 2 \mathrm{Jn} 7)$ and (3) "the one who came by water and blood, Jesus Christ" (1:7; $2: 1 f ; 4: 2,9,10,14$ [15]; 5:6; cf also 3:16). These three creedal formulas reflect the basic Christological tenets of the opponents (cf Whitacre 1982:123; Schnackenburg 1992:18f). This is verifiable from the negations (ớ , [also o

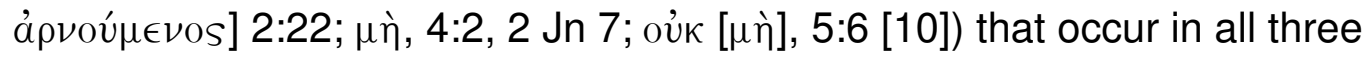
these references.

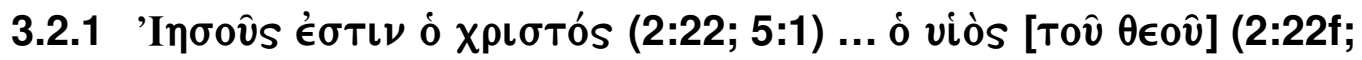 $4: 15 ; 5: 5)$}

Related texts with explicit doctrinal references depicting the first Christological tenet of the opponents are:

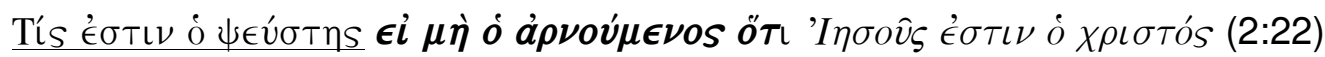 (negative)}

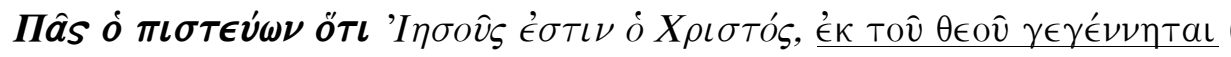
(positive)

\footnotetext{
${ }^{20}$ The Elder does not surrender the Christian claim to true and vital knowledge. It is hardly by chance that he uses the verb $\gamma(\nu \omega \sigma \sigma \kappa \in \nu \nu$, "to know", twenty-five times and oilden, "to know", fifteen times. He writes "we know" seventeen times, and "you (the readers) know" twelve times. The Elder and his adherents are the people who really know the gospel to which the church must firmly hold (Filson 1969:268f).

${ }^{21} 1$ John emphasizes certain tests that the adherents of the Elder are to apply to themselves to judge whether they are true or false Christians. One prominent phrase which accents certain tests is: ejn touvtw/ $(2: 3 ; 2: 5 ; 3: 10,16,19,24 ; 4: 2,6,13 ; 5: 2)$. Another pattern is the If clause: éàv (1:6f, 8ff; 2:3, 15, 24, 29; 3:21; 4:12, 20;5:15). In these if clauses, the verb is used in the subjunctive mood, but 2:19 uses $\epsilon i$ ('if'), and the indicative mood, in a contrary-to-fact condition, and 3:17 has ôs $\delta$ ' $\ddot{\nu} \nu$ and the subjunctive mood in the conditional relative clause. Filson (1969:264 fn 7) pointed out that all these passages involve a condition. These clauses show how serious the Elder was to set up tests and conditions by which Christian thoughts and actions could be guided.
} 
These two texts form an antithetical parallelism and a chiasm. The contents of both concern the denial/belief that "Jesus is the Christ". The one contradicts the other. Both texts are without any elaboration to qualify any meaning. The only help here, although vague, comes from 2:22f, where a parallelism (2:22), followed by an antithetical parallelism (2:23), occur.

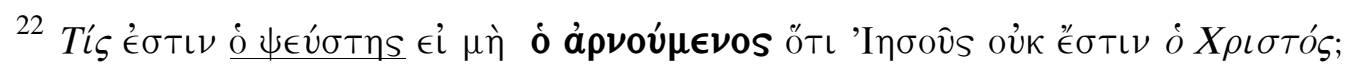

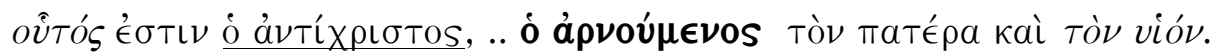

23

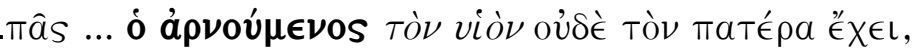

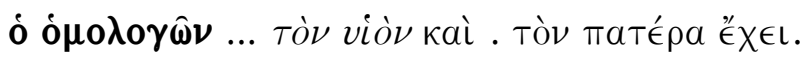

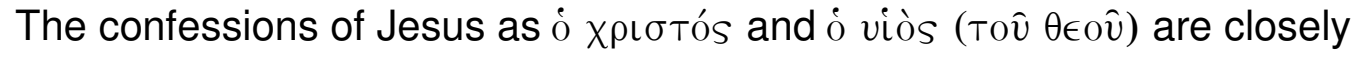
interrelated. They are virtually interchangeable. This is evident from 2:22-23 (cf also 5:1 with 5:5). ${ }^{22}$ To predicate one of them to Jesus is to be conscious of the other as well and to deny one regarding Jesus is to deny the other as well (Whitacre 1982:123; Schnackenburg 1992:145). According to this Christology the Elder wants to point out that Jesus is "the Son [of God]" and "the Christ". Thus "the Son [of God]" and "the Christ" is the same person, namely, Jesus or Jesus is "the Son [of God]" as well as "the Christ". ${ }^{23}$

The parallelism in 2:22 clearly illustrates that if Jesus is the Christ, he is the Son of God. If he is denied to be the Christ, then he is not the Son, which implies that such a denial would also be a denial of the Father. This is explicitly stated in the antithetical parallelism in 2:23. The issue here then

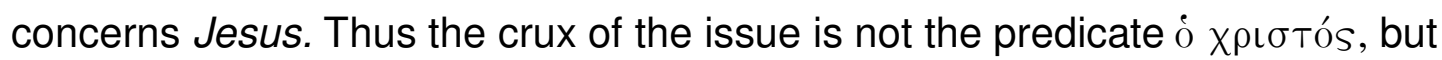
the subject 'I $\eta \sigma o v$ s. It is not because the opponents thought someone else was the Christ (e g the false christs of Matt 24:5); but the issue "was whether the man Jesus could be the same person as the divine Christ" (Brown 1982:352).

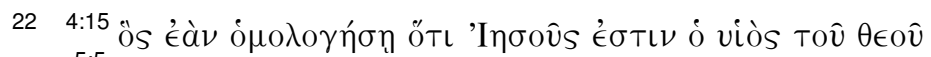

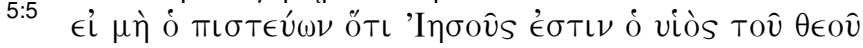

${ }^{23}$ De Jonge (1977:200-5; also Schnackenburg 1992:145) has pointed out that this close

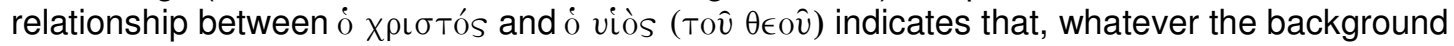
of $\delta$ X Christian experience in the Christian communities. In a comparison of the Fourth Gospel with 1 and 2 John, $\dot{o}$ xpı $\sigma$ Tós has even less reference to Jewish expectations. Of the eleven

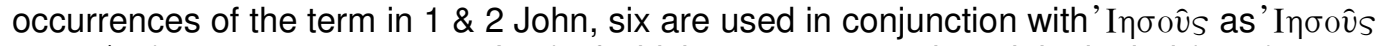

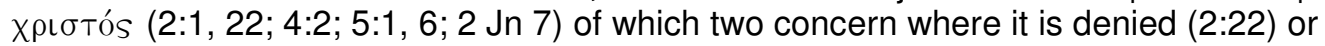
believed (5:1) that "Jesus is the Christ." In four other texts $(1: 3 ; 3: 23 ; 5: 20 ; 2 \mathrm{Jn} 3)$ Christ is

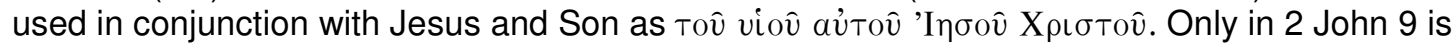

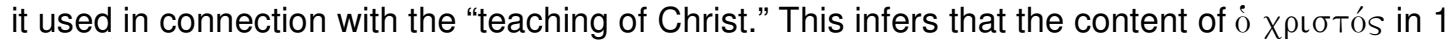
John is influenced by that of 'I 
It is difficult to determine from these verses what the opponents were

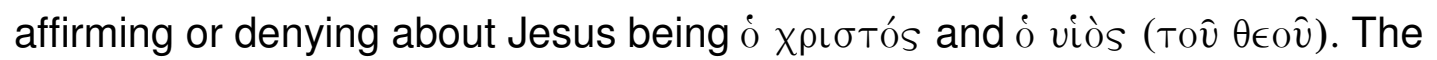
following Christological statement will give more clarity on this problem (cf Whitacre 1982:125).

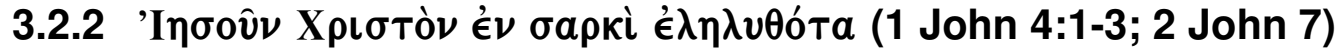

The second Christological tenet of the opponents concerns the "coming of Jesus Christ in the flesh", which is referred to in 4:2 and 2 John 7:

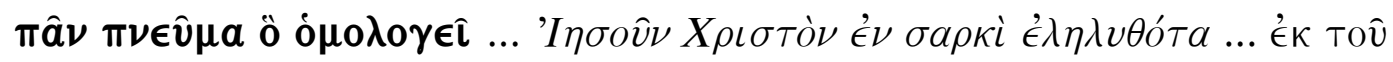
$\theta \in \mathrm{ov} \epsilon ́ \sigma \tau \iota \nu(4: 2)$ (positive)

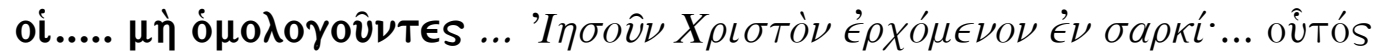

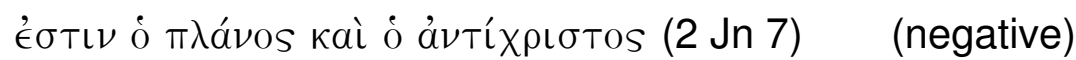

Here another antithetical parallelism occurs. The contents of both concern the confession or denial that "Jesus Christ has come in the flesh." The one confession is the opposite of the other; so are also the results of these confessions. The confession that

'I

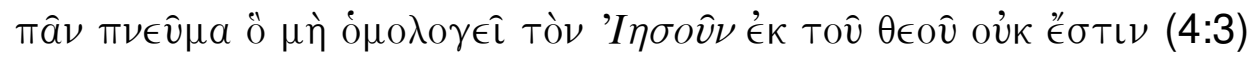

Verse $4: 2$ is contrasted with $4: 3$ and help to clarify the issue here.

This issue here, already present in 2:22 and 5:1, also concerns Jesus (Xpıбтò $\nu$ is omitted in 4:3). The issue is not whether Jesus has come in the flesh. This clause could refer only to confessing (or denying) that Jesus is "the Christ who came in the flesh"; that the expected Messiah has arrived on earth and he is Jesus. With such a confession, 4:2 would make more specific the confession that Jesus is the Christ as stated in 2:22 and 5:1. ${ }^{24}$ Hence, 4:2 is concerned with Jesus as ó Xpıбтós, therefore the Elder's use of the double

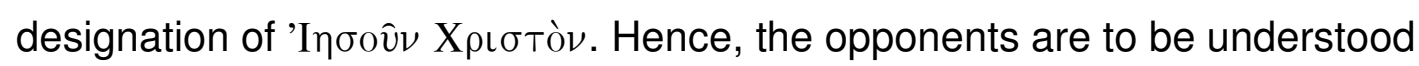

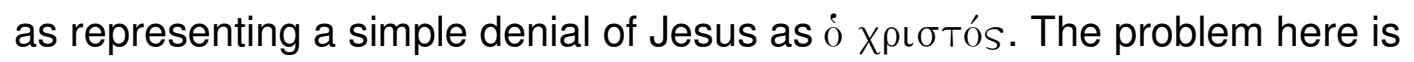

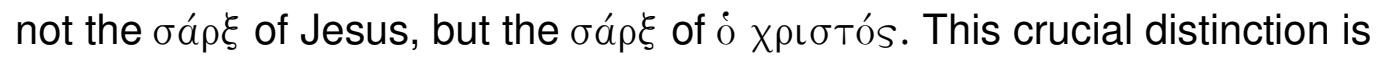

\footnotetext{
${ }^{24}$ See Whitacre (1982:127ff) for a valuable discussion on the Fourth Gospel's use of the noun $\sigma a ́ p \xi$ with reference to Jesus. He tries to point out that e.g. for the Fourth Evangelist the point was never that the resurrected Jesus has a body, but that the flesh and blood body standing in front of his disciples is the Jesus who was crucified. According to the Fourth Gospel it was the death of Jesus which gives life to the world and savrx is most likely an element in this motif.
} 


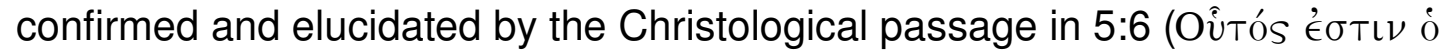

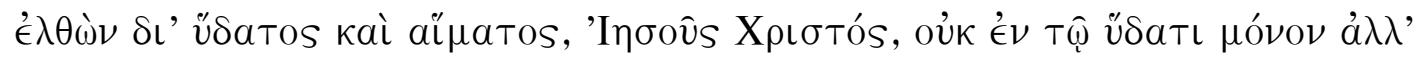

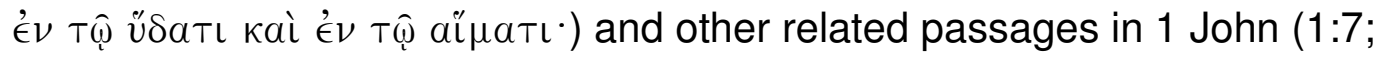
2:1f; 3:16; 4:9, 10, 14[15]).

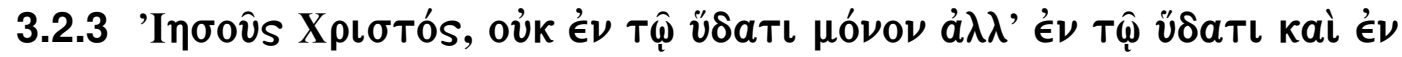
T⿳亠丷厂 aí $\mu$ atı (1 John 5:6)

This verse cryptically takes the nature of the false teaching of the opponents to a final point. In 1 John 5:6 the Elder indicates that the opponents, while accepting his baptism, deny the death of Jesus:

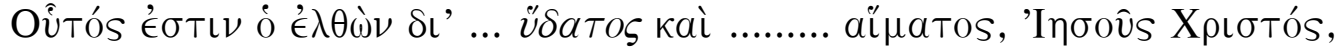

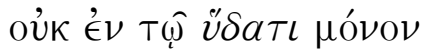

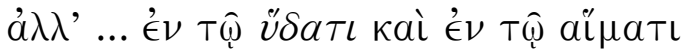

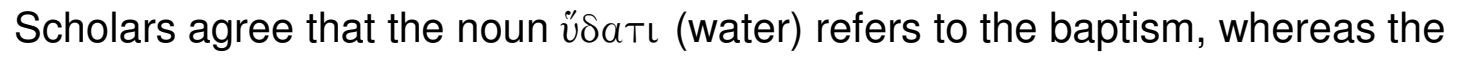
noun aí $\mu a \tau$ (blood) refers to his death. The death of Christ plays a central role throughout the entire epistle. It is with the rejection of this death by the opponents that the Elder is most concerned. ${ }^{25}$ It is through this death of

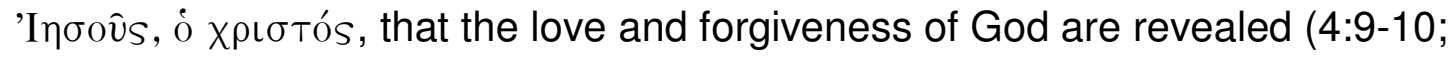
cf also $1: 7 ; 2: 1 f$ ) and fellowship is constituted in the familia Dei. According to the Elder, to deny that Jesus died as the Christ, is to deny the essence of

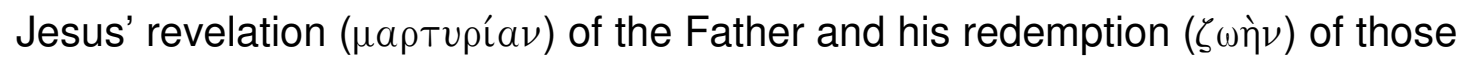

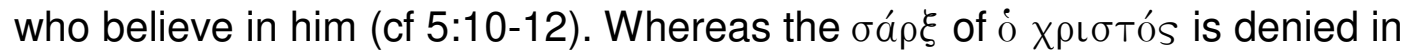
$4: 2$, the essential identity of Jesus as the Christ, his expiatory death, is denied in 5:6. Thus, the opponents denied that Jesus died as the Messiah. This is confirmed by all the other references in 1 John that support this conclusion (see footnotes $25 \& 26$ ).

\subsubsection{Conclusion}

Jesus and Christ occur and are related in all three the Christological tenets discussed above.

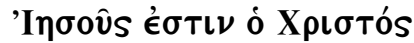

'I Xрıбтòv

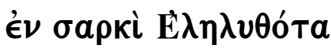

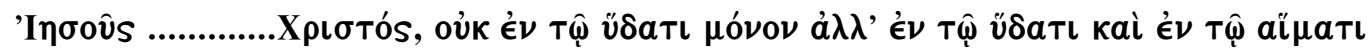

\footnotetext{
${ }^{25} \mathrm{Cf}$ all the references throughout 1 John to the death and crucifixion of Jesus: blood of Jesus (1:7); atoning sacrifice (2:2); he laid down his life for us (3:16); sent his only Son into the world so that we might live through him (4:9), to be the atoning sacrifice for our sins (4:10), as saviour of the world $(4: 14)$; came by water and blood $(5: 6,7)$. All the references to Jesus as (eternal) life also imply the cross event $(1: 1,2 ; 2: 25 ; 5: 11-13,20)$. Even the references "Jesus is the Christ" and "Jesus Christ" imply the death of Jesus.
} 
It has been pointed out that the Christological problem is not the denial of the fact that Jesus has come in the flesh. It is the denial that Jesus is "the Christ (who is the Son of God) that came in the flesh" (4:2) and that he, as the Christ, through his death revealed God par excellence and brought salvation for humankind. He constitutes koinonia in the familia Dei. Therefore, for the Elder, the denial of the "coming of Christ in the flesh" and the "atoning death of Christ" is the denial that "Jesus is the Christ."

Due to the many direct and indirect references to the death of Jesus Christ ${ }^{26}$ throughout 1 John, it seems as if the Elder, in his Christology, wants to focus on and emphasise the atoning death of Jesus as the Christ. With this doctrine the Elder tries to lead his adherents to understand why these opponents cannot enjoy fellowship with God and with one another, and why they block their own way to salvation (cf Schnackenburg 1992:145).

Serious ethical problems emanate from these doctrinal (pneumatological and Christological) issues.

\subsection{The ethical issues: The denial of sin and the disobedience to love} Influenced by Schnackenburg's (1992:77) literary analysis, Painter (2002:90; cf also Whitacre 1982:122; Johnson 1993:29, 39, 117; Culpepper 1998:256ff) recognizes "seven slogan-like" assertions that characterize the conduct of these opponents and strengthen the tension in the community. These assertions seem to encapsulate their "true ethical claims." They are grouped in dictums introduced by quotation formulae. Six of these assertions occur in the first major section (1:5-2:28) of 1 John, while the seventh $(4: 20)$ is closely related to the sixth. These assertions are cyclically developed throughout the epistle.

\subsubsection{The first group of assertions}

Following the prooemium the Elder turns to one of the decisive issues. In 1:5, the beginning of the first major section of the epistle, the Elder states that God is light. The inference drawn from this affirmation was that since there is no darkness in God, there can be no darkness in his followers. His opponents were denying that they were guilty of sinning. It seems that they thought that through their belief in Jesus they had become enlightened, could claim to be living in the light, and were free from $\sin .{ }^{27}$ While holding to the same tradition,

\footnotetext{
${ }^{26} \mathrm{Cf} 1: 7 ; 2: 1 \mathrm{f} ; 3: 16 ; 4: 9,10,14[15]$. All these texts refer to the expiatory death of Christ:

${ }^{27}$ Most of the references to $\sin$ are in the singular. This entails that it calls attention to the principle or fact of $\sin$ in human life (e $\mathrm{g} 1: 8$ ), rather than individual acts of sin.
} 
the Elder argues that those with such an understanding are badly deceived. He briefly discusses this in 1:5-2:2.

These verses (1:5-2:2), which form a sub-section, are organized around a group of three assertions. Each concerns the place of sin in the life of the believer. They express conditions that are misguided and destructive $(1: 6,8,10)$. Since the three undesirable conditions each begin with the phrase "Eà $\nu \epsilon$ " $\pi \omega \mu \epsilon \nu$ ("if we say"), it is reasonable to assume that some members of the community were making these assertions and others were in danger of accepting these views. ${ }^{28}$ These claims seem clearly to represent views advanced by the false teachers (Hiebert 1988:332; Culpepper 1998:257; Hurtado 2003:414).

The following table contains a synopsis of the opponents' false claims regarding sin:

\begin{tabular}{|c|c|c|c|}
\hline & ASSERTIONS & $\begin{array}{l}\text { CONDEMNATIO } \\
\mathbf{N}\end{array}$ & $\begin{array}{l}\text { CONSEQUENC } \\
\text { E }\end{array}$ \\
\hline $1: 6$ & 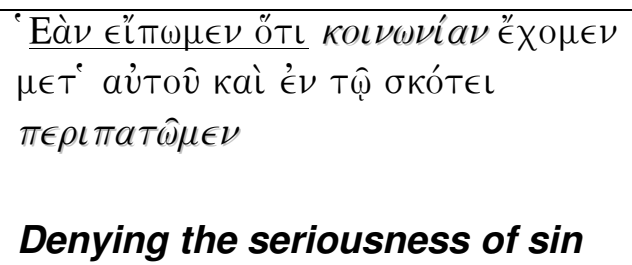 & $\psi \in v \delta o ́ \mu \epsilon \theta a$ & 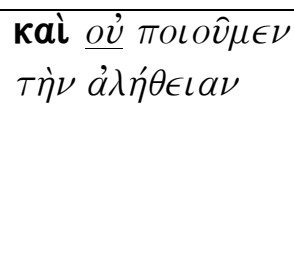 \\
\hline $1: 8$ & 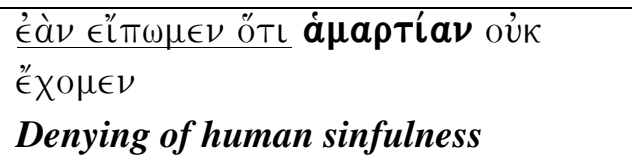 & $\begin{array}{l}\text { ÉavToùs } \\
\pi \lambda a \nu \hat{\omega} \mu \in \nu\end{array}$ & 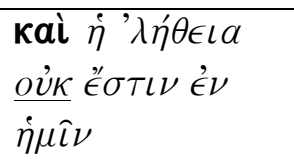 \\
\hline $1: 10$ & 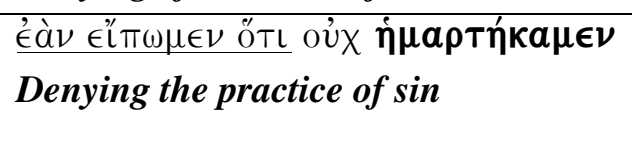 & 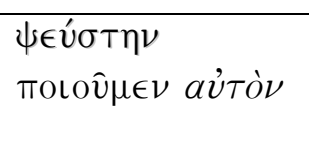 & $\begin{array}{l}\text { кaì } \dot{o} \lambda \hat{\gamma} \gamma o \varsigma \\
a \dot{v} \tau o \hat{v} \text { oúk }{ }^{\prime} \sigma \tau \iota \nu \\
\dot{\epsilon} \nu \dot{\eta} \mu \hat{\imath} \nu\end{array}$ \\
\hline
\end{tabular}

In this sub-section, the Elder starts the protasis of verses 6,8 and 10 with

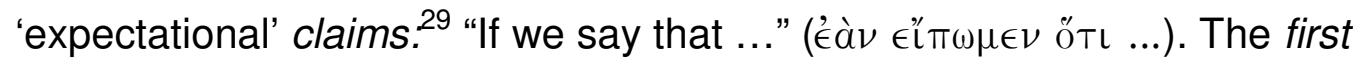

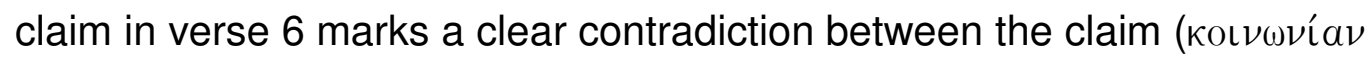

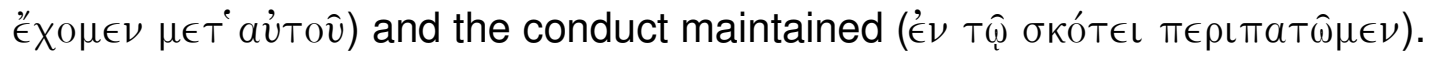
Verses 8 and 10 relate to verse 6 in the sense that it is as wrong to deny, as a

\footnotetext{
${ }^{28}$ Three tests are laid down by him in the form of false claims introduced by the conditional

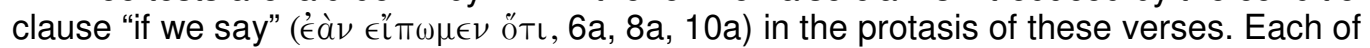
these three tests consists of two parts: the first positive and the second negative (cf Bruce 1970:42). The first part contains a claim, the second a condemnation with a negative consequence. In the first two tests the correctives (introduced by a conditional particle éà $\nu$ ) are supplied in verses 7 and 9 . In the third test (also '́à $\nu, 2: 1 f$ ) the Elder advances to a higher level. Instead of supplying another corrective, he moves over to the provision made to address the problem of sin.

${ }^{29}$ Hiebert (1988:332) interprets all three the claims in 1:6, 8, 10 as "hypothetical" To interpret it as "expectational" claims seems to be closer to the truth.
} 
way of conduct, both human sinfulness $(1: 8)$ and the practice of $\sin (1: 10)$ in one's life.

In the apodosis of these verses $(1: 6,8)$ the Elder pronounced a condemnation on this conduct by stating that "we lie" ( $\psi \in v \delta o ́ \mu \in \theta a$ / Éavtoùs $\pi \lambda \alpha \nu(\hat{\omega} \mu \in \nu)$. In his condemnation of these claims the Elder announces a verdict. In verses 6 and 8 he describes it as falsehood on man's part. However, in verse 10 the Elder defines the condemnation even more strongly with reference to God. The claim of being without sin suggests falsehood on God's part; it "makes him out to be a liar" ( $\psi \in \dot{v} \sigma \tau \eta \nu)$.

The consequences of such claims are that they hamper fellowship with both God and other believers in the family (cf 1:6,7). Such a person walks in darkness: "we are not practicing the truth" (1:6); and "the truth has no place in us" (1:8). This proves that these opponents do not have God's word abiding in them.

\subsubsection{The second group of assertions}

Like the previous sub-section, 1 John 2:3-11 contains three allusions to the claims of the Elder's opponents. Rather than following the earlier patterns which relate these claims in conditional sentences, the Elder reports them using the formula ó $\lambda \epsilon^{\prime} \gamma \omega \nu$ ("he who says ..." in $2: 4,6,9$ ). The following tabled analysis of 2:3-11 spells out these assertions.

\begin{tabular}{|c|c|c|}
\hline ASSERTIONS & TEST & CONSEQUENCE \\
\hline 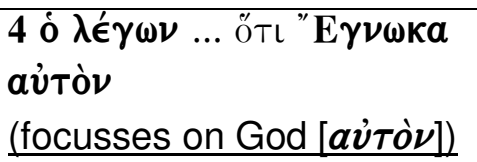 & 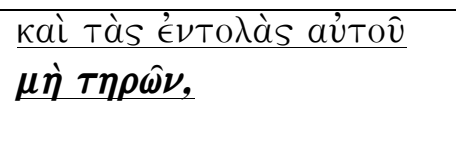 & 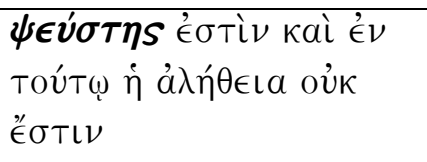 \\
\hline 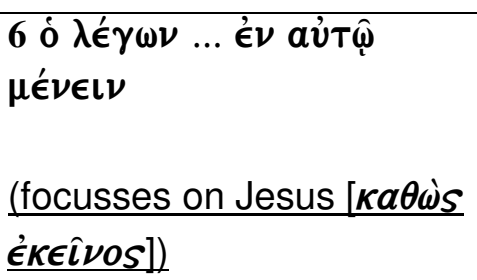 & 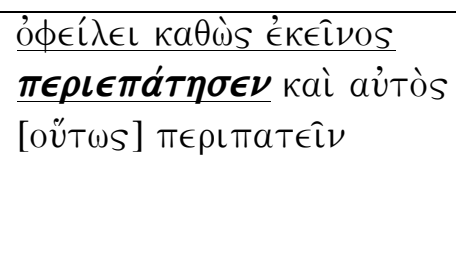 & 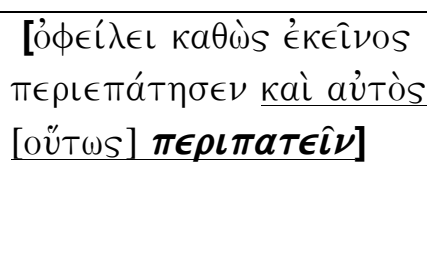 \\
\hline 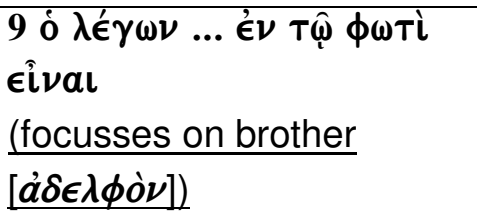 & 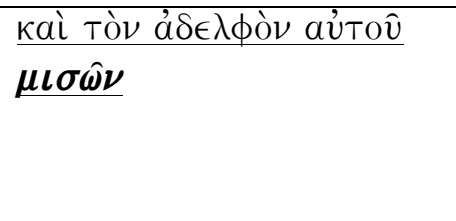 & 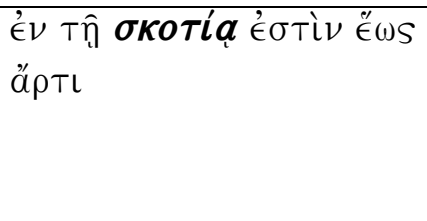 \\
\hline
\end{tabular}


This trio of false claims relate to being in a right relationship with God/Christ/brother: ${ }^{30}$ knowing God (2:4); abiding in Christ (2:6); being in the light (2:9). All three assertions have in common their emphasis of "the observance of the commandment of love for one another" (cf Johnson 1996:39). The opponents were guilty of this. Their doctrine and ethics caused them to look down upon those who did not conform to their doctrine and ethics. Therefore, they could not announce the reality of these claims stated in $2: 4,6,9$.

These claims are not in themselves false or objectionable. The Elder might well make each of these claims with regard to himself and his adherents. His point is that those who make such claims must show through the way they live that they are speaking the truth. By implication it may be concluded that his opponents made precisely these claims but did not maintain a pattern of life consistent with their claims. Again the ethical test of love falsifies the claim made by the opponents. Their lack of love for their

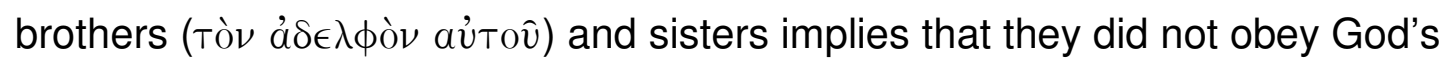
commandments and consequently did not live as Jesus lived. The consequences - they are accused by the Elder of being liars, and therefore ( $\ddot{\epsilon}^{\prime} \omega s$ ä $\left.\rho \tau \iota\right)$ people living in darkness. It is only when such love has realised in the lives of God's children that it can be said that they have the truth in them and live as Jesus lived.

\subsubsection{The last assertion}

This group includes only one assertion (4:20), as indicated in the following analysis:

\begin{tabular}{|c|c|c|}
\hline ASSERTIONS & TEST & CONSEQUENCE \\
\hline 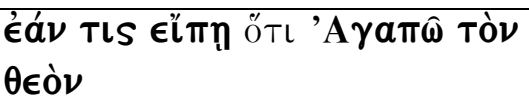 & 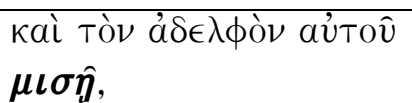 & $\psi \in \dot{v} \sigma \tau \eta S$ é $\sigma T^{\prime} \nu$ \\
\hline
\end{tabular}

This assertion is introduced by the formula éá $T$ TS Eltm ("if anyone says", 4:20). The first four of the first six assertions are seemingly given in the words of the opponents. The quotation is signalled by the ötı-particle followed by the words quoted in the first person "l" or "we" (Arndt \& Gingrich 1957:593 n2; Danker 2000:732). Here the formula 'If anyone says' is followed by a öTlrecitativum. The assertion is "I love God". These are apparently the words of the opponents.

\footnotetext{
${ }^{30}$ In this sub-section no explicit references to God or Christ occur. Even from the context it is not always clear to which person the personal pronouns or verbs refer.
} 
If the treatment of the sixth claim ends with the test of loving the brother, the seventh claim, "I love God" (4:20), is shown to be false by the absence of brotherly love. This can be seen in the parallel of these two statements:

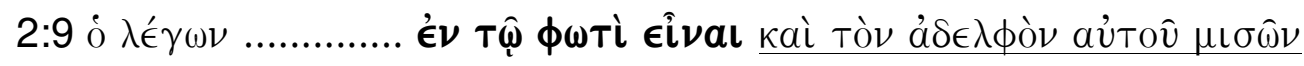

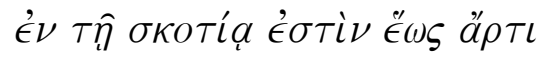

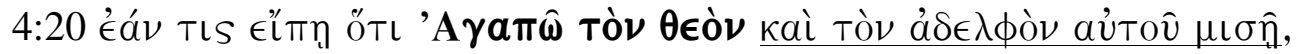 $\psi \epsilon \dot{v} \sigma \tau \eta \varsigma \dot{\epsilon} \sigma \tau i \nu$}

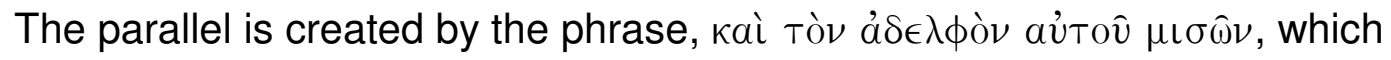
occurs in both texts. According to this parallel, the statement "to walk in the light" is equivalent to "I love God." Even the consequences are the same, although they are stated differently. Hence, these opponents do not love God or walk in the light. They are liars and are still in darkness because they hate (do not love) some of their brothers in the community. ${ }^{31}$ This absence of love is evident in the schism they caused, and according to $3: 16 f$ they showed no concern for the needs of others.

The Father is the source of love $(4: 8,16)$, and love is defined in terms of his love for his children. But if a person hates his brother but claims to love God, the Elder says that he is a liar ( $\psi \in \in$ vi $\sigma \eta s)$. In the apodosis part of the verse, hating the brother is equated with "not loving his brother." For the Elder, not to love is to hate. The Elder states categorically that "those who do not love a brother (or sister) whom they have seen cannot love God whom they have not seen." What is referred to here is not a single act, but a way of being (Painter 2002:284f).

\subsubsection{Conclusion}

Through their claimed spiritual illumination, the opponents also claimed to have attained a state beyond ordinary Christian morality in which they had no more sin and had already attained a form of moral behaviour that would enable them to continue to resist sin. Because of this spiritual illumination they discriminated against others in the familia Dei in a way that led to a lack of love and hostility. This is sensible in the consistent pattern that occurs in the seven assertions: assertion - test (condemnation) - consequence. These two

\footnotetext{
${ }^{31}$ In these assertions the Elder portrays his opponents very negatively. In the seven

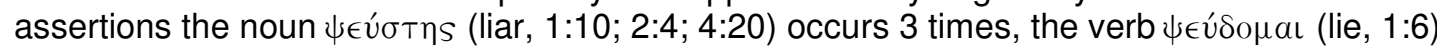
once and the verb $\pi \lambda a \nu \alpha$ a $\omega$ (deceive, 1:8) once. Two more negative consequences are also

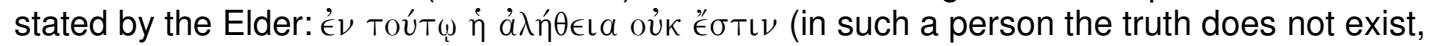

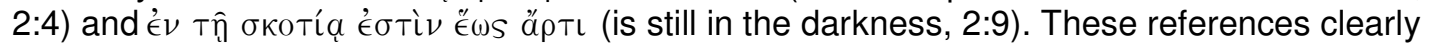
characterise and refer to the conduct of the opponents. They harmed the fellowship in the familia Dei.
} 
basic ethical problems are cyclically developed throughout 1 John where new perspectives are added to emphatically address these problems.

\section{CONCLUSION}

This article dealt with the identification and examination of the elements that caused the controversy and schism in the Johannine community at the end of the first century CE according to 1 and 2 John. The depiction of the two groups involved in this controversy, the opponents of the Elder on the one side and his adherents on the other side, prepared the agenda for the identification of these elements. It seems that the controversy in the Johannine Community was based on differences in the interpretation of a shared tradition (Brown 1982:69f; Von Wahlde 1994:108; Culpepper 1998:256; Kenney 2000b:102) about the "Pneumatology" and "Christology" which subsequently resulted in a difference in "Ethics." This had catastrophic consequences for the future existence of the Johannine community.

This controversy and schism, as reflected in these two epistles reveals that the Johannine community was an embattled community in their experience of internal conflict (and external conflict with the synagogue according to the Fourth Gospel). In time the community withdrew further from the world and adhered to the teachings and new commandment of Christ, mediated to them by the Elder. The depiction of this community is ironic - the last references to the Johannine community depict it as a community torn apart by conflict and struggling for survival. Wrecked by the schism, it collapsed. The adherents of the Elder were probably assimilated into other streams of Christianity during the early second century while the opponents of the Elder found their way into Gnostic communities of the mid-second century (cf Culpepper 1975:287; 1998:61).

\section{Works consulted}

Achtemeier, P J, Green B \& Thompson, M M 2001. Introducing the New Testament: It's literary and theology. Grand Rapids, MI: Eerdmans.

Arndt, W F \& Gingrich, F W 1957. A Greek-English Lexicon of the New Testament and other Early Christian Literature. London: The University of Chicago Press.

Botha, J E 2005. Simple salvation, but not a straw ... Jacobean Soteriology, in Van der Watt, J G (ed), Salvation in the New Testament: Perspectives on Soteriology, 389-408. Leiden: Brill.

Brown, R E 1979. The community of the beloved disciple: The life, loves and hates of an individual church in New Testament times. London: Geoffrey Chapman.

Brown, R E 1982. The Epistles of John. New York: Doubleday.

Bruce, F F 1970. The Epistles of John. London: Pickering \& Inglis. 
Bultmann, R 1971. The Gospel of John, tr by Beasley-Murray G R. Oxford: Basil Blackwell. (Anchor Bible.)

Cullmann, O 1976. The Johannine circle, tr by J Bowden. London: SCM.

Culpepper, R 1975. The Johannine school. Missoula, MT: Scholars.

Culpepper, R A 1998. The Gospel and Letters of John. Nashville, TN: Abingdon.

Danker, F W (ed) 2000. Greek English Lexicon of the New Testament and other Early Christian Literature, $3^{\text {rd }}$ rev ed. Chicago, IL: University of Chicago Press. (BDAG.)

De Jonge, M 1977. Variety and development in Johannine christology, in De Jonge M (ed), Jesus: Stranger from heaven and Son of God: Jesus Christ and the Christians in Johannine perspective, 193-213. Missoula, MT: Scholars Press. (SBL 11.)

Duling, D C 2003. The New Testament: History, literature, and context. Belmont, CA: Wadsworth.

Edwards, R B 1996. The Johannine epistles. Sheffield: Sheffield Academic Press.

Filson, F V 1969. First John: Purpose and message. Interpretation 23, 259-276.

Grayston, K 1984. The Johannine Epistles. Grand Rapids, MI: Eerdmans (The New Century Bible Commentary.)

Haas, C, De Jonge, M \& Swellengrebel J L 1972. A translater's handbook on the Letters of John. London: United Bible Societies.

Hiebert, D E 1988. An expositional study of 1 John. Bibliotheca Sacra 145, 329-342.

Hurtado, L 2003. Lord Jesus Christ (Devotion to Jesus in Earliest Christianity). Grand Rapids, MI: Eerdmans.

Johnson, T F 1993. 1, 2, and 3 John. Peabody, MA: Hendrikson. (New International Biblical Commentary.)

Kenney, G C 2000b. Leadership in John: An analysis of the situation and strategy of the Gospel and the Epistles of John. New York: University Press of America.

Lassen, E M 1997. The Roman family: Ideal and metaphor, in Moxnes, H (ed), Constructing Early Christian families: Family as social reality and metaphor, 103-120. London: Routledge.

Lieu, J 1986. The second and third epistles of John. Edinburgh: T \& T Clark.

Malina, B J 1982. The social sciences in Biblical interpretation. Interpretation 37, 229242.

Malina, B J 1986. Christian origins and cultural anthropology: Practical models for Biblical interpretation. Atlanta, GA: John Knox.

Malina, B J 1993. The New Testament world. Philadelphia, PA: Fortress.

Malina, B J 1996. The social world of Jesus and the Gospels. London: Routledge.

Martyn, J L 1979. History and theology in the Fourth Gospel. Nashville, TN: Abingdon.

Neufeld, D 1994. Reconceiving texts as speech acts: An analysis of 1 John. Leiden: Brill.

Painter, J 2002. 1, 2, and 3 John. Collegeville, MN: Liturgical Press.

Pax Romana. http://en.wikipedia.org/wiki/ Pax_Romana. Wikipedia, the free encyclopedia. 08/10/2006; 21h10.

http://www.encyclopedia.com/doc/1B1-374732.html. 20/05/2007; $13 \mathrm{~h} 45$.

http://history.enotes.com/history-fact-finder/eras-their-highlights/what-was-paxromana. 20/05/2007; $13 \mathrm{~h} 45$

http://www.unrv.com/early-empire/pax-romana.php. UNRV History. 08/10/2006; $21 \mathrm{~h} 10$. 
Perkins, P 1979. The Johannine Epistles. [S.I.]: Veritas.

Robbins, V K 1996. Exploring the texture of texts: A guide to socio-rhetorical interpretation. Valley Forge, PA: Trinity Press International.

Sandnes, K O 1997. Equality within patriarchal structures: Some New Testament perspectives on the Christian fellowship as a brother- or sisterhood and a family, in Moxnes, $\mathrm{H}$ (ed), Constructing early Christian families: Family as social reality and metaphor, 150-165. London: Routledge.

Schnackenburg, R 1992. The Johannine Epistles. New York: Crossroad.

Smalley, S S 1984. 1, 2, 3 John. Dallas, TX: Word Books. (WBC vol 51.)

Strecker, G 1996. The Johannine letters: A Commentary on 1, 2, and 3 John. Minneapolis, MN: Fortress.

Thomas, J 2004. C. A Pentecostal Commentary on 1 John, 2 John, 3 John. Cleveland: The Pilgrim Press.

Van der Merwe, D G 2003. ' $\Omega \rho \alpha$ the setting for understanding Johannine eschatology. Acta Patristica Et Byzantina 13, 253-285.

Van der Merwe, D G 2005. Understanding "sin" in the Johannine Epistles. Verbum et Ecclesia 26(2), 543-570.

Van der Watt, J G 1992 Interpreting imagery in John's Gospel: John 10 and 15 as case studies, in Barkhuizen, J H, Stander H F, \& Swart G J (eds), Hupomnema: Feesbundel Opgedra aan J P Louw, 272-282. Pretoria: University of Pretoria Press.

Van der Watt, J G 1999. Ethics in First John: A literary and socio-scientific perspective. QBC 61, 491-511.

Von Wahlde, U C 1990. The Johannine commandments: 1 John and the struggle for the Johannine tradition. New York: Paulist Press.

Whitacre, R A 1982. Johannine polemic: The role of tradition and theology. Chico, CA: Scholars Press. 